
\title{
Preserch Square \\ Investigation of The Long-Term Seasonal Variability of Precipitation And Temperature Across Turkey
}

Nida Doğan Çiftçi ( $\nabla$ doganni@itu.edu.tr)

Istanbul Technical University https://orcid.org/0000-0002-5022-5449

Ahmet Duran Şahin

Istanbul Technical University

Keywords:

Posted Date: June 17th, 2021

DOI: https://doi.org/10.21203/rs.3.rs-159545/v1

License: (c) (i) This work is licensed under a Creative Commons Attribution 4.0 International License.

Read Full License 


\section{Abstract}

The authors have requested that this preprint be removed from Research Square. 